\title{
Research and Practice of Tourism Education Practical Teaching in Higher Vocational Colleges
}

\author{
Liang Ruyue
}

\author{
Chongqing City Management College, Chongqing, 401331, China
}

\begin{abstract}
Keywords: tourism education, business needs, Tourism Management, Higher Vocational Colleges

Abstract. Tourism Teaching in Higher Vocational Colleges should not only improve the students' professional service ability, train a large number of high-quality tourism talents for the country, but also effectively promote the development of the tourism industry. Therefore, Higher Vocational tourism colleges should adhere to the "take the service as the goal, take to cultivate student' ability as the key point, take the social demand as the guidance" teaching philosophy, and use the "Orientation training, off campus practice, school enterprise cooperation"teaching mode, and constantly optimize the teaching resources, to make the students have a full range of promotion in professional quality and occupation accomplishment, of course this also plays a very important role and significance in social development
\end{abstract}

\section{The present situation of Tourism Management Specialty in Higher Vocational Colleges}

\subsection{Teaching characteristics of Tourism Management Specialty in Higher Vocational}

Tourism Management Major in Higher Vocational Colleges to improve students' practical ability as the foundation, its purpose is to cultivate students' comprehensive quality, so that the students can all-round development in morality, At the same time to cultivate students with certain knowledge on the basis of tourism management, Master the skills of the society for tourism professionals, which has a good professional quality of Tourism Foreign Language and communication ability, computer operation ability, sense of service and team cooperation consciousness, strain capacity and the ability to adapt.

\subsubsection{The theory system is perfect}

Although China's Tourism Management Major of Higher Vocational Education in the long-term creation has formed a relatively complete system of teaching theory, but the theory system has restricted the students' practice operation, so many of the current higher vocational tourism professional teachers only pay attention to the theoretical teaching for students.

\subsubsection{Involving a wide range}

Tourism management professional requirements students must have extensive knowledge, which is decided by the nature of the tourism industry, the third industry (service industry), so the higher vocational colleges should cultivate students from the full range of all aspects.

\subsubsection{Professional practical operation}

The Tourism Management Major students' Employment is relatively broad, it relates to the scenic spots, travel agencies, hotels and other service industries, so students must have strong professional practical ability.

\subsection{The role of practical teaching in Tourism Management Major in Higher Vocational Colleges}

\subsubsection{It is conducive to cultivate students' innovation ability and professional quality}

Practice teaching of Tourism Management Specialty in Higher Vocational Colleges can improve students' innovation ability and occupation accomplishment, and it is also the effective way to cultivate students' creative thinking. In the actual operation process, students understand the difference between theory and practice through real feelings, and constantly to hold the spirit of inquiry of theory knowledge, this teaching mode not only help the students have a better understanding of the theoretical knowledge of the classroom, but also improve the ability of the practical application of the students, let the students in practice constantly discover and solve problems. 


\subsubsection{Convergence with business needs}

Tourism Management Teaching in higher vocational colleges, through the continuous transport of students to the enterprise learning, make the students' professional research can better adapt to the development of enterprise. At the same time, this kind of teaching mode based on school practice teaching of new technology, and constantly adjust the problems in the practice teaching process, can achieve the goal of seamless connection between talent and social needs.

\subsubsection{The number of Vocational Colleges and students which set up Tourism Management} Major

According to the latest survey data, in 2015 China's tourism management in higher vocational colleges is 1075 , tourism professionals in the country a total enrollment of 110935 people, among which the creation of Tourism Management Specialty in 779 universities in the country, enrollment of 48043 students, involving tourism professional institutions a total of 108, 3492 students, guide professional universities and colleges have 102, enrollment of 3889 students, opened a tourism agency related professional universities and colleges in 29 , enrollment of 808 people, involving the scenic area service and management professional institutions in 45, enrollment of 996 students, opened tourism services and management colleges and universities in 22, enrollment of 944 students.

The survey selected three local higher vocational tourism colleges as the object of investigation, a total of 800 questionnaires, effective recovery of 765 copies

The contents and results of the survey are shown in the following table 


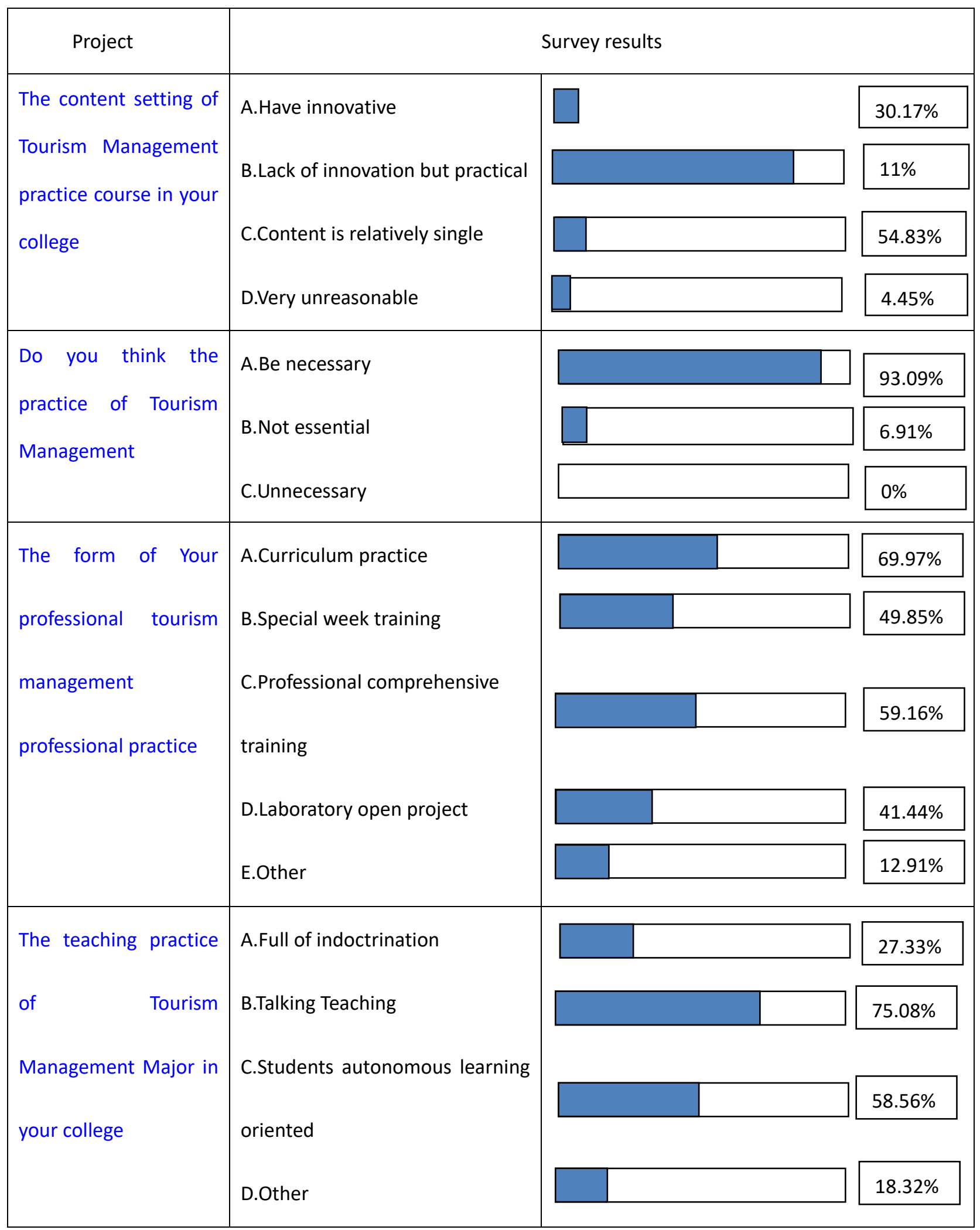

Analysis of the results of the questionnaire: the two local vocational colleges of tourism professional practice teaching content is single, lack of innovation and practicality, while most students think that practical courses is very necessary, and the form of practice is relatively fixed, there is no specific, teachers' teaching methods are mainly based on students' discussion and autonomous learning, lack of favorable guidance. 


\section{Analysis on practical teaching of Tourism Management Major in Higher Vocational Colleges}

\subsection{The goal setting of practical teaching is not clear enough}

Although the current higher vocational tourism management professional training target is clear, but for the tourism practice teaching goal is not clear. The main performance is the curriculum is not reasonable, practice teaching hours is very small, teachers do not pay enough attention to professional practice, make the theoretical teaching and the practice of serious disconnection. The reason for these phenomena is that the teacher not according to the actual situation of the students to formulate tourism practice teaching plan reasonably, and ignore the difference between teaching content and practical teaching, that is to say, the aim of teaching practice is vague and unclear.

\subsection{Lack of content and form of practice teaching}

In the content of practice teaching of Tourism Management Major of Higher Vocational Colleges, the problem of practice is relatively fixed and concentrated and the form is too single are Ubiquitous, usually students practice time will be arranged after the completion of a semester teaching, teachers can lead the students to the tourist attractions, travel agencies, tour of hotel to have a simple practice, after students returning to school, according to the needs of teachers to the topic and task results of practical learning feedback. The practice teaching method has seriously hindered the students' autonomous learning and creativity, and practice teaching form cannot match the the demand of the society.

\subsection{Practice teaching condition restriction}

At present, tourism management major in Higher Vocational Colleges' practice conditions can not meet the actual needs of the students in China, the existing practice base for operating mainly in the form of a travel agency or hotel, this is very limited to the ability of students to practice, and the teaching effect is not obvious.

\subsection{Practical teaching quality is not high}

Most of the practical teachers are the theoretical teaching teachers of the school, and most of the teachers for colleges to colleges, students to teachers, so the practical teaching teachers are not rich experience, for enterprise business processes and enterprise culture does not understand, so students can not to be a good guide, can not reach the real purpose of practice teaching

\subsection{Lack of practice teaching management}

At present our country higher vocational tourism colleges in the teaching practice of the management there are many problems, many colleges and universities do not give timely feedback to teachers' teaching, at the same time for the evaluation system of teaching management of teachers also do not perfect, the teaching content and form of some teachers is not carried out in accordance with the syllabus, and arbitrarily change the teaching contents, some teachers in order to improve the students' achievements in teaching will appear only test knowledge, for students to understand some of the teachers don't relate to.

\section{Construction of practical teaching mode of Tourism Management Specialty in Higher Vocational Colleges}

\subsection{To make clear the goal of practical teaching}

College of Higher Vocational Tourism Management Major should clear teaching objectives, constantly carry out the new curriculum reform, at the same time, pay enough attention to the practice teaching, either as teachers or the management of colleges, should be the practice of tourism management major students as the research object and discuss the key of daily work. 


\subsection{Improve the content and form of practice teaching}

Vocational tourism colleges should make reasonable arrangements for the theory and practice of teaching in class, teachers can adjust the teaching content and teaching methods according to the feedback from students in the classroom teaching, and strong convergence of difference between theory and practice, and continue to introduce advanced teaching methods, continuous innovation of teaching, use a variety of forms of teaching to stimulate students interest in learning and enthusiasm, at the same time, the school arrange for students to practice learning, should constantly immersed in cooperation with enterprises and units, so that the students can really put theoretical knowledge into practical work.

\subsection{Establish a good practice teaching conditions}

The school should strengthen the practice of teaching facilities, which can meet the practical needs of the students, establish and improve the training room, and must combine with the theory of knowledge. Of course Higher Vocational Colleges in China can also be modeled by some tourist attractions or enterprise business processes, to simulate the real environment for the students to learn.

\subsection{To strengthen the construction of teaching staff}

Arrange travel professional teachers to work in the enterprise, take on-the-job training of teachers in practice constantly, continue to attract outstanding tourism professionals, and the school should carry out regular teaching seminars in order to improve the professional quality of teachers.

\subsection{Establish and improve the practice management mechanism}

Higher vocational tourism colleges should establish and improve the teaching management system, strengthen the inspection and supervision of teachers' teaching, and make the evaluation of practice teaching, on one hand is the evaluation between teachers, on the other hand is the students' evaluation of teachers, at the same time, the management should fully do the investigation and feedback, adjust constantly for the problems in practical teaching, so as to establish and improve the practice management system of Tourism Management Specialty in Higher Vocational Colleges.

\section{Acknowledgement}

The paper is the research results of the project "Research and Practice on the Talent Cultivation of Higher Vocational Tourism Management Major from the Perspective of Competence Based Education" which is supported by the Chongqing Education Science "13th Five-Year" planning project (Grant Number:2016-GX-022)

\section{References}

[1] Wei Wen. Research on the reform of talent training mode in Vocational and Technical College of tourism hotel professional -- Taking the First Occupation College of Huludao City as an Example [J]. Journal of Jilin radio and TV University, 2014 (3).

[2] Sang Qingqing. Research on the actuality and Countermeasures of students' professional practice of tourism hotel professional -- Taking An Hui international Business Vocational College as an example [J]. New education era electronic magazine, 2016 (9).

[3] Gong Xue. University elective course tourism geography -- Please describe the regional characteristics of tourism resources in China. [J]. Tourism Geography, 2015 (7) 